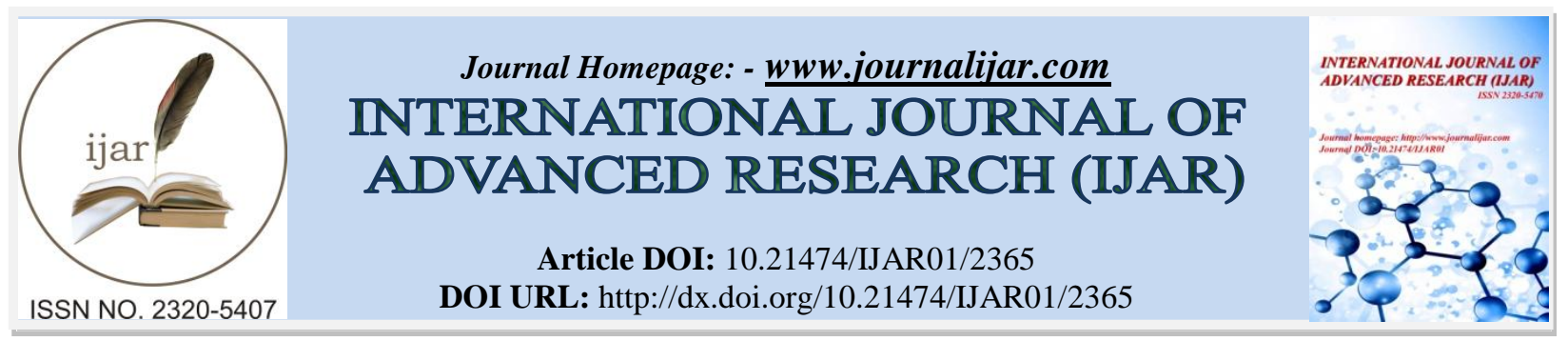

RESEARCH ARTICLE

\title{
DIAGNOSTIC VALUE OF RIZ1 GENE EXPRESSION AS A POTENTIAL MARKER FOR PATIENTS WITH HEPATOCELLULAR CARCINOMA.
}

\author{
Khaled Metwaly ${ }^{1}$, Mohamed Abbasy ${ }^{1}$, Talaat Zakareya ${ }^{1}$, Eman Abdel-Sameea ${ }^{1}$, Abdel Moaty Oda ${ }^{1}$, \\ Mahmoud El Tahawy ${ }^{2}$, Ayman Azzam², Samar Ghanem² and Fathia Elbassal ${ }^{3}$. \\ 1. Hepatology Department, National liver institute, Menoufiya University, Egypt. \\ 2. Clinical Biochemistry Department, National liver institute, Menoufiya University, Egypt. \\ 3. Clinical Pathology Department, Faculty of Medicine, Menoufiya University.
}

\section{Manuscript Info}

[..........................

Manuscript History

Received: 18 October 2016

Final Accepted: 20 November 2016

Published: December 2016

\section{Abstract}

Introduction:- There is still a need for novel biomarkers to improve the early detection of hepatocellular carcinoma (HCC). The retinoblastoma protein-interacting zinc finger gene (RIZ1) expression and activity are reduced in many human cancers by genetic and epigenetic mechanisms. Its role in HCC still not clear.

Aim:- To evaluate the expression of RIZ1 gene in patients with HCC. Methods:- The expression of RIZ1 gene was assessed by real time PCR in 48 consecutive patients with HCC, 23 patients with HCVrelated liver cirrhosis, and 25 healthy controls. Measurement of serum alpha feto protein (AFP).

Results:- Patients with HCC, cirrhosis and controls were matched regarding sex (males, n (\%): 40 (80), 19 (76) and 22 (88) respectively, $\mathrm{P}=0.852)$ and age $(58.3 \pm 10.2,54.8 \pm 9.0$ and $54.0 \pm 10.8$ respectively, $\mathrm{P}=0.150$ ). Median AFP in patients with $\mathrm{HCC}$ was $994.9 \mathrm{ng} / \mathrm{ml}$. RIZ1 gene expression (folds) was significantly lower in patients with HCC $(1.51 \pm 1.48)$ compared to patients with cirrhosis $(13.32 \pm 10.93$, $\mathrm{P}<0.0001)$ and controls $(18.70 \pm 9.38, \quad \mathrm{P}<0.0001)$. RIZ1 gene expression (folds) was significantly lower in patients with small tumour $(<3 \mathrm{~cm})$ compared to those with large $(\geq 3 \mathrm{~cm})$ tumors $(0.75 \pm 0.72$ vs. $1.79 \pm 1.59$ respectively, $\mathrm{P}=0.001)$ and in patients with no distant metastases compared to those with distant metastases (Median: 0.12 vs 1.17 respectively, $\mathrm{p}=0.016$ ).

Conclusion:- RIZ1 gene expression may be used as a diagnostic and prognostic marker for HCC as it is significantly reduced in patients had HCC and in cases without distant metastases as well.

Copy Right, IJAR, 2016,. All rights reserved.

\section{Introduction:-}

Hepatocellular carcinoma (HCC) is one of the most serious and life threatening complications of chronic liver disease. It is the $5^{\text {th }}$ most common malignancy in men and $7^{\text {th }}$ in women (1). It is the $2^{\text {nd }}$ most common malignancy related mortality worldwide with 745,000 deaths per year (2). Its incidence is continuously increasing throughout the world (3-5). In Egypt, between 1993 and 2002, there was an almost two fold increase in HCC among patients with chronic liver disease (6). Surveillance should therefore be considered particularly trans-abdominal ultrasound which 
is adapted by many guidelines as the only cost-effective tool $(7,8)$ The role of serum biomarkers as alpha-fetoprotein (AFP), which is the most widely used, has been stepped down because of low sensitivity and specificity (8-11).

Historically, many markers are used for HCC screening, AFP remains the most commonly used screening biomarker for HCC, although its role is controversial. AFP is known to have poor sensitivity specially in smaller tumors (25\% sensitivity at tumor size $<3 \mathrm{~cm}$ ).(12) in addition to low specificity as it is secreted from both tumor cells and growing cells (91.4\%).[13]. Des-gamma-carboxyprothrombin is produced by malignant hepatocytes, and showing better sensitivity than AFP,(14) but this sensitivity goes down with small tumors.(15). Another HCC biochemical marker are Glypican-3 (GPC3), and lens culinary agglutinin-reactive fraction of AFP (AFP-L3\%). AFP-L3 has a pooled sensitivity of $48.3 \%$ (95\% confidence interval [CI]: $45.9-50.7)$ and a pooled specificity of $92.9 \%$ (95\% CI: 91.6-94.0); area under the curve was 0.76.(16), so it is not suitable for HCC screening. GPC3 has a pooled sensitivity and specificity off $69 \%$ and $83 \%$, respectively.(17,18). Finally,Insiulin growth factor II (IGF-II) motivates HCC and different cancer cell growth and increases survival both in vitro and in vivo(19).Several clinical studies have demonstrated elevated IGF-II levels in both tumors and blood from HCC patients, indicating a role of IGF-II as a marker of HCC $(20,21)$. Other studies found less evidence of an association between IGF-II and HCC (22). Therefore, discovery of a novel, reproducible, inexpensive marker with high sensitivity and specificity represent a target that will improve surveillance program for HCC.

The retinoblastoma protein-interacting zinc finger gene (RIZ), was isolated in a functional screening for retinoblastoma-binding proteins. The RIZ gene maps to short arm of chromosome lp36. RIZ contains a novel protein methyl transferase domain, called the positive regulatory (PR) domain, hence the other name PR domain methyl transferase (PRDM2) (23). The RIZ gene encodes two products: RIZ1 that contains the PR domain and RIZ2 that lacks the domain (23). The RIZ is considered a tumor-suppressive gene as RIZ1 has tumor-suppressive properties by inducing G2-M arrest and apoptosis (23). Its deletion or loss of heterozygosis has been reported in various human cancers, including malignant lymphoma and plastic crisis of chronic myelogenous leukemia (24). The decreased expression of RIZ1 has been reported in breast and gastric carcinomas due to inactivation of the RIZ1 gene by promoter hypermethylation $(25,26)$.

Deregulation of the epigenome (the totality of epigenetic markers in a cell, including DNA methylation, histone modification and non-coding RNAs) is thought to play an important role in tumor development and progression (27). Epigenetic events are considered key mechanisms in the regulation of gene activity, and abnormal expression of a large number of tumor suppressor genes and cancer-associated genes has been observed in a wide range of human cancer (28). DNA methylation has been primarily studied in the context of gene transcription and aberrant gene silencing, although it has been implicated in the silencing of transposable elements (29). DNA methylation impacts the level of compaction of chromatin, and this affects the interaction between DNA and transcription factors, and consequently influences DNA expression. Global genome hypomethylation is a common phenomenon found in many solid tumors, including HCC (30).

The aim of our study was to evaluate the expression of RIZ1 gene in HCC patients in an attempt to improve our ability to detect the disease at an earlier stage.

\section{Subjects and Methods:-}

Ninety six persons were included in the study and allocated in 3 different groups after obtaining the approval of the local ethics committee and informed consent from all eligible subjects. HCC group includes forty eight (48) consecutive patients diagnosed with HCC on top of HCV-related cirrhosis. The diagnosis of HCC was based on the presence of hepatic focal lesion(s) larger than $1 \mathrm{~cm}$ in abdominal ultrasonography that showed the characteristic vascular enhancement pattern of HCC (hypervascular in the arterial phase with washout in the portal venous or delayed phase) with either 4-phase multidetector CT scan or a contrast enhanced dynamic MRI). For patients with atypical vascular enhancement pattern, a second contrast enhanced dynamic imaging or histopathological confirmation was needed. Cirrhosis group contains 25 consecutive patients with HCV-related liver cirrhosis. Clinical, abdominal imaging (ultrasound, CT or MRI) as well as laboratory findings were done to diagnose cirrhosis and exclude HCC in this group. The severity of cirrhosis was graded according to Child-Pugh classification. Control group included 23 consecutive apparently healthy individuals with matched age and sex.

Blood Samples: Venous blood $(5 \mathrm{ml})$ was collected from all the included subjects and divided into EDTA (stored at -80 until the RNA was extracted) and plain tubes (centrifuged, then the clear supernatant sera were separated from 
the sediment RBCs and collected in aliquots for assessment of AFP using automated fiber and tap placement technique, liver tests and viral markers (HBsAg and anti-HCV).

\section{RIZ1 detection by real-time reverse transcription polymerase chain reaction (RT-PCR):-}

1. RNA extraction: Total RNA was extracted using the GeneJET RNA Purification Kit (Fermentas, Germany), which utilizes a silica-based membrane technology in the form of a convenient spin column following the manufacturer's protocol. The purified RNA was used for reverse transcription immediately or stored at $-70^{\circ} \mathrm{C}$ until use.

2. Reverse transcription: was carried out using the RevertAid First Strand cDNA Synthesis Kit (Promega Corporation, Madison, WI, USA). Briefly, to prepare the first-strand cDNA, $1 \mu \mathrm{l}$ of random hexamer primer and $6 \mu \mathrm{l}$ of nuclease-free water were added to $5 \mu \mathrm{l}$ of template RNA in a sterile, nuclease-free tube placed on ice. This was followed by incubation at $65^{\circ} \mathrm{C}$ for $5 \mathrm{~min}$ and addition of $4 \mu \mathrm{l}$ of reaction buffer, $1 \mu \mathrm{l}$ of Ribolock RNase inhibitor, $1 \mu \mathrm{l}$ of dNTPs mix, and $1 \mu \mathrm{l}$ of Moloney murine leukemia virus reverse transcriptase (MMLV) RevertAid. The contents of the tube were mixed gently and centrifuged, and then tubes were placed in a thermal cycler for $5 \mathrm{~min}$ at $25^{\circ} \mathrm{C}$, followed by $60 \mathrm{~min}$ at $42^{\circ} \mathrm{C}$. The reaction was terminated by heating at $70^{\circ} \mathrm{C}$ for 5 min.

3. Quantitative real-time monitoring of PCR product: Master mix was prepared for both the RIZ1 gene (gene of interest) and the glyceraldehyde 3-phosphate dehydrogenase (GAPDH) gene (internal control gene) separately in the following order: $1 \mu \mathrm{l}$ of forward primer, $1 \mu \mathrm{l}$ of reverse primer, $0.25 \mu \mathrm{l}$ of ROX dye, $5 \mu \mathrm{l}$ of cDNA, $5 \mu \mathrm{l}$ of SYBR green master mix (Applied Biosystems Inc., Foster City, CA, USA), and $7.75 \mu$ of DNase-free water to reach a total volume of $20 \mu \mathrm{l}$. Thermal cycling for 45 cycles was repeated as follows: $50^{\circ} \mathrm{C}$ for $2 \mathrm{~min}, 94^{\circ} \mathrm{C}$ for $12 \mathrm{~min}, 94^{\circ} \mathrm{C}$ for $15 \mathrm{~s}$, and $60^{\circ} \mathrm{C}$ for $1 \mathrm{~min}$. The sequence of primers for the RIZ1 gene was as follows: forward: 5/TGGCTGCGATATGTGAATTG-3/ and reverse: 5/-CTTTCCGGCTCTTGGGGG-3/ and primers for the GAPDH gene were forward: 5/-TGCACCACCAACTGCTTAGC-3/ and reverse: 5/GGCATGGACTGTGGTCATGAG-3/.

The 7300 real-Time PCR System was used (Applied Biosystems Inc., Foster City, CA, USA). The sensitivity of the assay was verified by gel electrophoresis of the amplified PCR products and melting curve analysis of the primers.

The expression levels of the RIZ1 gene in unknown samples were normalized and analyzed by the 2- $\Delta \mathrm{ct}$ method where $2-\Delta \mathrm{ct}=(\mathrm{ct} \text { RIZ1 }- \text { ct GAPDH })_{\text {sample }}-(\mathrm{ct} \text { RIZ1-ct GAPDH })_{\text {calibrator }}$. After all reactions, the average 2- $\Delta$ ct from control samples combined was defined as 1.0 (calibrator) and the relative difference in expression against GAPDH expression was compared with the expression in control cells. All reactions were performed in duplicates and a negative control without template was included in each run.

\section{Statistical analysis:-}

Data were analyzed using SPSS (Statistical Package for Social Sciences) version 13 for Windows (SPSS Inc., Chicago, IL, USA). Tests for significance among the groups or in the HCC group were used accordingly. ANOVA and independent t-test for comparison of means, Mann-Whitney $U$ and Kruskal Wallis tests for comparison of medians in parametric and non-parametric data, respectively. Chi-square test was used to compare frequencies. Pearson's and Spearman's correlation coefficients were used for parametric and non-parametric correlations respectively.

For all analyses, two-sided $\mathrm{p}$ value was calculated and considered statistically significant if less than 0.05 .

\section{Results:-}

The HCC, cirrhosis and control groups, were comparable regarding age $(\mathrm{p}=0.150)$ and sex $(\mathrm{p}=0.852)$. The RIZ1 gene expression was significantly lower in patients with HCC compared to both cirrhosis and control groups $(\mathrm{p}<0.001)$, while it showed no statistical significant difference in the cirrhosis and control groups $(\mathrm{p}=1.000)($ table 1). Patients with HCC showed no difference regarding the Child-Pugh class, as most of the patients in the latter group were class $\mathrm{C}$ followed by $\mathrm{B}$ and $\mathrm{A}(\mathrm{n}=31,64.6 \% ; 12,25 \%$; and $5,10.4 \%$, respectively) ( $\mathrm{p}=0.659)$.

In HCC group, most of the patients had large tumors ( $\geq 3 \mathrm{~cm}, \mathrm{n}=35,72.9 \%)$, with distant metastases $(\mathrm{n}=34,70.8 \%)$, stage IV TNM $(\mathrm{n}=30,62.5 \%)$. The median serum level of AFP was $994.9 \mathrm{ng} / \mathrm{ml}$. The RIZ1 gene expression was significantly lower in small tumors and tumors with distant metastases than large tumors and tumors without distant metastasis ( $\mathrm{p}=0.001$, and $\mathrm{p}=0.003$ respectively), (table 2$)$. The RIZ1 gene expression was comparable among the 
Child-Pugh classes ( $\mathrm{p}=0.132$ ) and between early (I-III) and advanced (IV) TNM stages ( $\mathrm{p}=0.079)$ (table 2). The RIZ1 gene expression was significantly correlated with the serum total bilirubin $(\mathrm{p}=0.009)$, but not with albumin $(\mathrm{p}=0.240)$ or TNM stage $(\mathrm{p}=0.519)($ table 3$)$.

Table 1:- Demographics and RIZ1 gene expression of the studied groups.

\begin{tabular}{|c|c|c|c|c|}
\hline & $\begin{array}{c}\text { HCC } \\
(n=48)\end{array}$ & $\begin{array}{c}\text { Cirrhosis } \\
(n=23)\end{array}$ & $\begin{array}{c}\text { Control } \\
(n=25)\end{array}$ & $\mathbf{P}$ \\
\hline Age (years), mean \pm SD & $58.3 \pm 10.2$ & $54.8 \pm 9.0$ & $54.0 \pm 10.8$ & 0.150 \\
\hline $\begin{array}{l}\text { Sex } \\
\text { Males, n (\%) } \\
\text { Females, n }(\%)\end{array}$ & $\begin{array}{l}38(79.2) \\
10(20.8)\end{array}$ & $\begin{array}{c}17(73.9) \\
6(26.1)\end{array}$ & $\begin{array}{c}20(80) \\
5(20)\end{array}$ & 0.852 \\
\hline RIZ1 gene expression (folds), mean \pm SD & $1.51 \pm 1.48$ & $13.32 \pm 10.93$ & $18.70 \pm 9.38$ & $\begin{array}{l}\mathrm{P} 1<0.001 \\
\mathrm{P} 2<0.001 \\
\mathrm{P} 3=0.011\end{array}$ \\
\hline
\end{tabular}

HCC, hepatocellular carcinoma; P1, HCC vs. cirrhosis; P2, HCC vs. control; P3, cirrhosis vs. control.

Table 2:- RIZ1 gene expression according to tumor characteristics in the HCC group.

\begin{tabular}{|c|c|c|c|}
\hline & n $(\%)$ & $\begin{array}{c}\text { RIZ1 gene expression (folds) } \\
\text { Mean } \pm \text { SD } \\
\end{array}$ & $\mathbf{P}$ \\
\hline \multicolumn{4}{|l|}{ Child-Pugh class* } \\
\hline $\mathrm{A}$ & $4(8.3)$ & $2.60(2.35)$ & \\
\hline $\mathrm{B}$ & $16(33.3)$ & $1.17(2.23)$ & 0.132 \\
\hline $\mathrm{C}$ & $28(58.3)$ & $0.79(2.18)$ & \\
\hline \multicolumn{4}{|l|}{ Tumor size } \\
\hline$<3 \mathrm{~cm}$ & $13(27.1)$ & $0.75 \pm 0.72$ & \multirow[t]{2}{*}{0.001} \\
\hline$\geq 3 \mathrm{~cm}$ & $35(72.9)$ & $1.79 \pm 1.59$ & \\
\hline \multicolumn{4}{|l|}{ Distant metastasis* } \\
\hline Positive & $14(29.2)$ & $1.17(2.29)$ & \\
\hline Negative & $34(70.8)$ & $0.12(1.40)$ & 0.016 \\
\hline \multicolumn{4}{|l|}{ TNM staging* } \\
\hline Early (I-III) & $18(37.5)$ & $1.17(2.16)$ & \multirow[t]{2}{*}{0.079} \\
\hline Advanced (IV) & $30(62.5)$ & $0.55(2.20)$ & \\
\hline
\end{tabular}

*Data are median (interquartile range).

HBsAg, hepatitis B surface antigen; HCV, hepatitis C virus; SD, standard deviation.

Table 3:- Correlation of RIZ1 gene expression with the characteristics in the HCC group.

\begin{tabular}{|l|c|c|}
\hline & R & P \\
\hline Age (years) & -0.08 & 0.420 \\
\hline Total bilirubin (mg/dl) & -0.371 & 0.009 \\
\hline Albumin (g/dl) & 0.160 & 0.240 \\
\hline ALT (IU/l) & -0.04 & 0.770 \\
\hline AST (IU/l) & 0.02 & 0.900 \\
\hline ALP (IU/I) & -0.21 & 0.150 \\
\hline GGT (IU/l) & -0.08 & 0.570 \\
\hline Total protein (g/dl) & -0.14 & 0.350 \\
\hline Alpha fetoprotein (ng/ml) & -0.236 & 0.149 \\
\hline Child-Pugh class* & -0.279 & 0.058 \\
\hline TNM staging* & -0.095 & 0.519 \\
\hline Distant metastases* & -0.241 & 0.139 \\
\hline
\end{tabular}

*Non-parametric correlation, Spearman's rho correlation coefficient.

ALT, alanine aminotransferase; ALP, alkaline phosphatase; AST, aspartate aminotransferase; GGT, gammaglutamyl transpeptidase. 


\section{Discussion:-}

It has been well established that, in addition to numerous genetic abnormalities, epigenetic changes play an important role in gene expression and HCC pathogenesis (11). The process involve methylation of CpG Islands located in the gene promotor region of a series of tumor suppression genes that resulted in transcriptional silencing of variety of genes, including those implicated in the regulation of cell survival, proliferation, differentiation and apoptosis (23). Reversed of these epigenetic processes and upregulation of genes are important to reverse the malignant phenotype and have become a potential therapeutic strategy in cancer treatment $(11,24)$.

The aim of the current study is to evaluate RIZ1 gene expression in HCC, hoping for using RIZ1 gene expression as a valuable tool for early detection of HCC paving the way for its utilization as target for epigenetic therapy. In the current study, RIZ1 gene expression was statistically significant decreased in HCC patients compared to cirrhosis $(\mathrm{p}<0.001)$ and control groups $(\mathrm{p}<0.001)$.

The same was reported by Jiang et al. who investigated the role of RIZ1 in tumorogenesis in hepatoma, through analyzing the expression of RIZ1 by RT-PCR assay on human Hepatoma cell lines which showed that the expression of RIZ1 was significantly decreased (RIZ1 transcripts- was undetectable in $80 \%$ of hepatoma cell lines (24).

This was supported by Fang et al, who reported that in study of 97 HCC cases they found that RIZ1 is commonly lost or under expressed in HCC, moreover, they found that RIZ1 gene can induce cell cycle arrest, apoptosis or both suppressing HCC tumorogenicity in nude mice. These finding is explained by the fact that RIZ1 is a PR domain methy transferase that methylates histone H3 lysine9, a modification impotent for transcriptional repression (25).

Altered expression of RIZl is not exclusive for HCC but it is also reduced in other malignancies as reported by Cheng et al(26) who found that RIZ1 expression is reduced or lost in cervical cancers, compared with normal cervical tissues . Lal et al. (27) demonstrated that RIZ1 expression is lost in thyroid tumor cell lines and is also significantly reduced in thyroid carcinomas, when compared with normal thyroid tissues $(\mathrm{p}<0.0001)$ and benign tumors $(\mathrm{p}=0.0003)$. Wen dong et al (28) found that RIZ1 gene is silenced in human esophageal squamous cell carcinoma and it is concentration is down regulated. Finaly Khaenam et al (29) found that (RIZ1) inactivated by promoter hypermethylation in patients with liver fluke-related cholangiocarcinoma (CCA).

Our analysis did not address the mechanisms of decreased RIZ1 expression, which need to be studied in different context.

Altered expression of RIZ1 gene in both hematological and non- hematological malignancies encourage searching for the explanation of its down regulation. Polymerase chain reaction (PCR) was used to investigate the promoter region methylation status and the following was reported:

Cheng et al (26) reported that down regulation of RIZ1 gene expression plays an important role in the development of acute myeloid leukemia, and this alteration is partially caused by RIZ1 gene promoter methylation. Lakshmikuttyamma et al. (30) stated that one possible explanation for decreased RIZ1 expression in CML blast crisis is that the RIZ1 promoter CpG islands was aberrantly hypermethylated, and that was proven by addition of a methylation inhibitor, 5-aza-2'-deoxycytidme, to CML blast crisis cell line which resulted in induction of RIZ1 expression, Such studies pave the way for using hypomethylating agents as a target therapy, that reverse CpG islands hypermetylation and hence RIZ1 gene down regulation. Molecular links between the modification of histone proteins and the methylation of DNA have led to the idea of combining both principles as a new epigenetic combination therapy in cancer (Venturelli et al (31).

In the current study, there was statistically significant association between decreased expression of RIZ1 gene and both small (less than $3 \mathrm{~cm})(\mathrm{p}=0.007)$ and advanced tumors (stage IV) $(\mathrm{p}=0.008)$. No correlation was found between RIZ1 gene expression and liver enzymes, viral markers and Alfa- fetoprotein ( $p>0.05)$. However, a significant correlation was found between RIZ1 gene expression and both serum albumin and serum bilirubin $(\mathrm{p}<0.05)$.

Similar results reported by Piao et al. (32), as they found that RIZ1-gene promoter is hypermethylated and inactivated both in early tumors $(<3 \mathrm{~cm})$ rather than in poorly differentiated $\mathrm{HCC}$ and advanced tumors $(>3 \mathrm{~cm})$ suggesting that the inactivation of RIZ1 by rather than particularly in the early stage of the disease. 
From this study, it was concluded that RIZ1 gene expression is significantly decreased in HCC patients with early tumor rather than in HCC patient with advanced stage. This makes RIZ1 gene expression a valuable tool for early detections, evaluation of progression, and epigenetic therapy of HCC patients on futures clinical trials.

\section{Conclusion:-}

RIZ1 gene expression may be used as a diagnostic and prognostic marker for HCC as it is significantly reduced with $\mathrm{HCC}$, tumors less than $3 \mathrm{~cm}$ and tumour without distant metastases.

\section{References:-}

1. MARTIN, M. \& HERCEG, Z. 2012. From hepatitis to hepatocellular carcinoma: a proposed model for crosstalk between inflammation and epigenetic mechanisms. Genome Med, 4

2. FERLAY, J., SHIN, H. R., BRAY, F., FORMAN, D., MATHERS, C. \& PARKIN, D. M. 2010. Estimates of worldwide burden of cancer in 2008: GLOBOCAN 2008. Int J Cancer, 127, 2893-917.

3. BRAIT, M. \& SIDRANSKY, D. 2011. Cancer epigenetics: above and beyond. Toxicol Mech Methods, 21, 27588.

4. KHAENAM, P., NIIBORI, A., OKADA, S., JEARANAIKOON, P., ARAKI, N. \& LIMPAIBOON, T. 2012. Contribution of RIZ1 to regulation of proliferation and migration of a liver fluke-related cholangiocarcinoma cell. Asian Pac J Cancer Prev, 13, 4007-11.

5. DONG, S. W., ZHANG, P., LIU, Y. M., CUI, Y. T., WANG, S., LIANG, S. J., HE, Z., SUN, P. \& WANG, Y. G. 2012. Study on RIZ1 gene promoter methylation status in human esophageal squamous cell carcinoma. World J Gastroenterol, 18, 576-82.

6. XIE, W., LI, X., CHEN, X., HUANG, S. \& HUANG, S. 2010. Decreased expression of PRDM2 (RIZ1) and its correlation with risk stratification in patients with myelodysplastic syndrome. Br J Haematol, 150, 242-4.

7. HE, L., YU, J. X., LIU, L., BUYSE, I. M., WANG, M. S., YANG, Q. C., NAKAGAWARA, A., BRODEUR, G. M., SHI, Y. E. \& HUANG, S. 1998. RIZ1, but not the alternative RIZ2 product of the same gene, is underexpressed in breast cancer, and forced RIZ1 expression causes G2-M cell cycle arrest and/or apoptosis. Cancer Res, 58, 4238-44.

8. BALLESTAR, E. \& ESTELLER, M. 2008. Epigenetic gene regulation in cancer. Adv Genet, 61, 247-67.

9. VAISSIERE, T., SAWAN, C. \& HERCEG, Z. 2008. Epigenetic interplay between histone modifications and DNA methylation in gene silencing. Mutat Res, 659, 40-8.

10. LIN, C. H., HSIEH, S. Y., SHEEN, I. S., LEE, W. C., CHEN, T. C., SHYU, W. C. \& LIAW, Y. F. 2001. Genome-wide hypomethylation in hepatocellular carcinogenesis. Cancer Res, 61, 4238-43.

11. ESTELLER, M. 2006. Epigenetics provides a new generation of oncogenes and tumour-suppressor genes. $\mathrm{Br} \mathbf{J}$ Cancer, 94, 179-83.

12. Marrero JA, Feng Z, Wang Y, Nguyen MH, Befeler AS, Roberts LR, et al. Alpha-fetoprotein, des-gamma carboxyprothrombin, and lectin-bound alpha-fetoprotein in early hepatocellular carcinoma. Gastroenterology 2009;137:110-118.

13. Nakamura S, Nouso K, Sakaguchi K, Ito YM, Ohashi Y, Kobayashi Y, et al. Sensitivity and specificity of desgamma-carboxy prothrombin for diagnosis of patients with hepatocellular carcinomas varies according to tumor size. Am J Gastroenterol 2006;101:2038-2043.

14. Yi X, Yu S, Bao Y. Alpha-fetoprotein-L3 in hepatocellular carcinoma: a meta-analysis. Clin Chim Acta 2013;425:212-220.

15. Yang SL, Fang X, Huang ZZ, Liu XJ, Xiong ZF, Liu P, et al. Can serum glypican-3 be a biomarker for effective diagnosis of hepatocellular carcinoma? A meta-analysis of the literature. Dis Markers 2014;2014:127831.

16. Jia X, Liu J, Gao Y, Huang Y, Du Z. Diagnosis accuracy of serum glypican-3 in patients with hepatocellular carcinoma: a systematic review with meta-analysis. Arch Med Res 2014;45:580-588.

17. H.M.Khandwala,I.E.McCutcheon,A.Flyvbjerg,K.E.Friend,Theeffectsofinsulin-like growth factors on tumorigenesis and neoplastic growth, Endocr. Rev. 21 (2000) 215-244.

18. J.G.Scharf,W.SchmidtSandte,S.A.Pahernik,G.Ramadori,T.Braulke,H.Hartmann, Characterization of the insulinlike growth factor axis in a human hepatoma cell line (PLC), Carcinogenesis 19 (1998) 2121-2128.

19. Z.Z. Dong, D.F. Yao, D.B. Yao, X.H. Wu, W. Wu, L.W. Qiu, D.R. Jiang, J.H. Zhu, X.Y. Meng, Expression and alteration of insulin-like growth factor II-messenger RNA in U. Espelund et al. / Growth Hormone \& IGF Research $\mathrm{xxx}$ (2015) $\mathrm{xxx}-\mathrm{xxx} 7$ hepatoma tissues and peripheral blood of patients with hepatocellular carcinoma, World J. Gastroenterol. 11 (2005) 4655-4660. 
20. J.F. Tsai, J.E. Jeng, L.Y. Chuang, H.L. You, M.S. Ho, C.S. Lai, L.Y. Wang, M.Y. Hsieh, S.C. Chen, W.L. Chuang, Z.Y. Lin, M.L. Yu, C.Y. Dai, Serum insulin-like growth factor-II and alpha-fetoprotein as tumor markers of hepatocellular carcinoma, Tumour Biol. 24 (2003) 291-298.

21. C. Morace, M. Cucunato, R. Bellerone, C.G. De, S. Crino, A. Fortiguerra, F. Spadaro, A. Zirilli, A. Alibrandi, P. Consolo, C. Luigiano, M.L. Resta, O. Ferrau, A. Spadaro, Insulin- like growth factor-II is a useful marker to detect hepatocellular carcinoma? Eur. J. Intern. Med. 23 (2012) e157-e161.

22. CHIBA, T., YOKOSUKA, O., ARAI, M., TADA, M., FUKAI, K., IMAZEKI, F., KATO, M., SEKI, N. \& SAISHO, H. 2004. Identification of genes up-regulated by histone deacetylase inhibition with cDNA microarray and exploration of epigenetic alterations on hepatoma cells. J Hepatol, 41, 436-45.

23. ARMEANU, S., PATHIL, A., VENTURELli, S., MASCAGNI, P., WEISS, T. S., GOTTLICHER, M., GREGOR, M., LAUER, U. M. \& BITZER, M. 2005. Apoptosis on hepatoma cells but not on primary hepatocytes by histone deacetylase inhibitors valproate and ITF2357. J Hepatol, 42, 210-7.

24. JIANG, G., LIU, L., BUYSE, I. M., SIMON, D. \& HUANG, S. 1999. Decreased RIZ1 expression but not RIZ2 in hepatoma and suppression of hepatoma tumorigenicity by RIZ1. Int J Cancer, 83, 541-6.

25. FANG, W., PIAO, Z., SIMON, D., SHEU, J. C. \& HUANG, S. 2000. Mapping of a minimal deleted region in human hepatocellular carcinoma to 1p36.13-p36.23 and mutational analysis of the RIZ (PRDM2) gene localized to the region. Genes Chromosomes Cancer, 28, 269-75.

26. CHENG, H. Y., GAO, Y. \& LOU, G. 2010. DNA methylation of the RIZ1 tumor suppressor gene plays an important role in the tumorigenesis of cervical cancer. Eur J Med Res, 15, 20-4.

27. LAL, G., PADMANABHA, L., SMITH, B. J., NICHOLSON, R. M., HOWE, J. R., O'DORISIO, M. S. \& DOMANN, F. E., JR. 2006. RIZ1 is epigenetically inactivated by promoter hypermethylation in thyroid carcinoma. Cancer, 107, 2752-9.

28. DONG, S. W., ZHANG, P., LIU, Y. M., CUI, Y. T., WANG, S., LIANG, S. J., HE, Z., SUN, P. \& WANG, Y. G. 2012. Study on RIZ1 gene promoter methylation status in human esophageal squamous cell carcinoma. World J Gastroenterol, 18, 576-82

29. KHAENAM, P., NIIBORI, A., OKADA, S., JEARANAIKOON, P., ARAKI, N. \& LIMPAIBOON, T. 2012. Contribution of RIZ1 to regulation of proliferation and migration of a liver fluke-related cholangiocarcinoma cell. Asian Pac J Cancer Prev, 13, 4007-11.

30. LAKSHMIKUTTYAMMA, A., TAKAHASHI, N., PASTURAL, E., TORLAKOVIC, E., AMIN, H. M., GARCIA-MANERO, G., VORALIA, M., CZADER, M., DECOTEAU, J. F. \& GEYER, C. R. 2009. RIZ1 is potential CML tumor suppressor that is down-regulated during disease progression. J Hematol Oncol, $2,28$.

31. VENTURElli, S., ARMEANU, S., PATHIL, A., HSIEH, C. J., WEISS, T. S., VONTHEIN, R., WEHRMANN, M., GREGOR, M., LAUER, U. M. \& BITZER, M. 2007. Epigenetic combination therapy as a tumor-selective treatment approach for hepatocellular carcinoma. Cancer, 109, 2132-41.

32. PIAO, G. H., PIAO, W. H., HE, Y., ZHANG, H. H., WANG, G. Q. \& PIAO, Z. 2008. Hyper-methylation of RIZ1 tumor suppressor gene is involved in the early tumorigenesis of hepatocellular carcinoma. Histol Histopathol, 23, 1171 